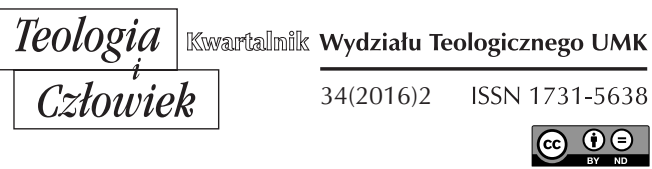

JAKUB WOŹNIAK*

TORUŃ

\title{
NIECHRZEŚCIJAŃSKIE ŹRÓDŁA LITURGII POGRZEBU I KULTU ZMARŁYCH WCZESNEGO CHRZEŚCIJAŃSTWA
}

DOI: http://dx.doi.org/10.12775/TiCz.2016.020

Historia człowieka ukazuje od samego początku jego istnienia szacunek wobec ciała. Świadczą o tym różnego rodzaju odkrycia archeologiczne, które ukazują cześć dla materii doczesnej człowieka. Wśród najbardziej spotykanych form wyróżnić można: pogrzeb w ziemi: na terenie Egiptu zwłoki były zwrócone głową w stronę wschodu, a w późniejszym okresie $\mathrm{w}$ stronę przeciwną, jak wierzono - w stronę królestwa zmarłych. Inną formą było pozostawienie ciała na powietrzu - na górze, w jaskinie, w wieży, a także na dachu (u Zaratustry), gdzie ciała wystawiane były na żer dzikich zwierząt, by nie sprofanować ognia. Kolejna forma polegała na zatopieniu ciała w wodzie oraz na kremacji.

* Jakub Woźniak - doktorant nauk teologicznych na Wydziale Teologicznym Uniwersytetu Mikołaja Kopernika w Toruniu; student drugiego stopnia nauk o rodzinie; członek Senatu UMK; przewodniczący Wydziałowej Rady Samorządu Studenckiego Wydziału Teologicznego UMK; prezes Koła Naukowego Cooperatores Veritatis im. Benedykta XVI. Zainteresowania: nauczanie Josepha Ratzingera (Benedykta XVI), teologia liturgiczna, teologia dogmatyczna, działalność Stolicy Apostolskiej (jakub88w@gmail.com) 
Te różnorodne formy pochówku ukazywały wierzenia i postawy ludzi, w których przekonaniu osoba zmarła nadal egzystuje na poziomie innego wymiaru ${ }^{1}$.

„Liturgia chrześcijańska, jak każda inna forma kultu religijnego, jest zakotwiczona w miejscu i czasie swego powstania; będąc wydarzeniem historycznym, nie mogła rozwijać się w całkowitej izolacji od warunków społeczno-politycznych i religijnych ówczesnego świata"2. Można więc zauważyć pewne elementy wspólne pomiędzy liturgią chrześcijańską a kultem hebrajskim, w którym chrześcijaństwo miało swoją inicjację. Podobne odniesienie można dostrzec w elementach „zapożyczonych” do chrześcijańskiej liturgii ze świata hellenistycznego, z którym chrześcijaństwo zetknęło się, kiedy zaczęło rozprzestrzeniać się po Imperium Rzymskim. Trzecią formą kultu, z którą miało styczność chrześcijaństwo był kult panujący w cesarstwie rzymskim, natomiast czwartą formą kultu, wśród której wzrastało chrześcijaństwo, był kult egipski. Liturgia Kościoła zakorzeniona jest więc w czterech wielkich kulturach ówczesnego świata: hebrajskiej, grecko-hellenistycznej, rzymskiej i egipskiej³.

${ }^{1}$ Por. Leksykon liturgii, red. B. Nadolski Poznań 2006, s. 788.

2 J.J. Janicki, Kultury antyczne w liturgii chrześcijańskiej, Kraków 2007², s. 11.

${ }^{3}$ Por. tamże, s. 11-12.

W tym miejscu warto przytoczyć słowa wielkiego znawcy liturgii i głównego propagatora Ruchu Liturgicznego, Odo Casela, który w swoim dziele na temat misterium kultu, ukazuje zależność kultu chrześcijańskiego od misteriów hellenistycznych: „Z pewnością nie możemy przenosić naszych klasycznych pojęć, z chrześcijańskiej symboliki do antycznych misteriów. Złączone są one z naturą, są służbą «żywiołów świata», jak mówi św. Paweł o kulcie judaistyczno-hellenistycznym (Kol 2,8.20; Ga 4,3.9); nie prowadziły one do nadprzyrodzonego życia prawdziwego Boga. Były one tylko cieniem, w porównaniu do chrześcijańskich misteriów. Ale były również tęsknotą, «cieniem tego, co przyszłe», jednakże ciałem, które ten cień rzucało, było «Ciało Chrystusa» (Kol 2,17), które również zarysowywało się w typach Starego Testamentu. Analogia, tak jak tkwi w całej naturze w stosunku do nadnatury, była właściwa także im, i w ten sposób były one w stanie użyczyć słów i form nadprzyrodzonym misteriom Chrystusa. Nie dawały im one bytu i treści. Jakże mogłyby te «słabe i biedne elementy», sięgnąć również do misteriów Chrystusa? Ale umożliwiły one danie ciała temu, co nowe i niepojęte w nowotestamentalnym Objawieniu Boga. [...] Całkowicie nowy sposób Służby Bożej, gminy chrześcijańskiej, nie mógłby być wyrażony przy pomocy starych terminów, oficjalnego żydowskiego lub pogańskiego języka kultowego". O. Casel, Chrześcijańskie misterium kultu, tłum. M. Wolicki, Kraków 2000, s. 111-112. 
W samym odniesieniu do liturgii należy zaznaczyć, że ma ona umożliwić jej uczestnikom „poznanie Bożej rzeczywistości i wejście w życiowy kontakt z Boskim Zbawicielem. Dlatego stało się sprawą bardzo ważną, aby słowa, gesty, postawy, szaty, elementy naturalne, wnętrze i urządzenie kościoła czy struktura obrzędów - były prawdziwie pomostem dialogu i wymiany (sacrosanctum commercium) człowieka i całego zgromadzenia liturgicznego z Bogiem"4.

Chcąc jednak mówić o liturgii chrześcijańskiej pogrzebu i jej pogańskich źródłach, nie sposób nie wyjaśnić podstawowych trzech pojęć związanych z przysposabianiem ${ }^{5}$ elementów niechrześcijańskich do wiary chrześcijańskiej. Pierwszym z nich jest pojęcie „akomodacji” (określanej także jako adaptatio minor, adaptacja ${ }^{6}$ mniejsza), „która w głównej mierze odnosi się do liturgii i polega na dostosowaniu elementów nie tyle kultury, ile elementów samej celebracji do danej sytuacji egzystencjalnej, rodzaju zgromadzenia, wieku uczestników itp. W praktyce dotyczy ona doboru modlitw, czytań oraz zakresu i sposobu wyrażania i przepowiadania prawd wiary i chrześcijańskiej moralności"7.

Drugim jest „akulturacja” (określana także jako adaptatio maior). „Polega ona na modyfikacjach w środkach wyrazu wiary (głównie w przepowiadaniu i obrzędach liturgicznych) opartych na kulturze danego narodu. Akulturacja to zmiany strukturalne i formalne (w tym językowe); [...]. Innymi słowy, akulturacja to znalezienie takich elementów danej kultury, którymi można zastąpić bądź wyjaśnić środki, wyrażenia wiary ogólnie przyjęte i mające jednoznaczny sens na przykład w europejskiej kulturze zachodniej, ale niezrozumiałe w kulturze, w której wprowadza się chrześcijaństwo. [...] Można powiedzieć, że akulturacja to proces włączenia

${ }^{4}$ J.J. Janicki, Kultury antyczne, s. 184.

5 Termin ten można również zastąpić pojęciem „adaptacja liturgiczna”, która w odniesieniu do liturgii obejmuje różne dziedziny: tj. muzykę, architekturę, obrzędy, przede wszystkim zawarcie małżeństwa, pogrzeb, postawy ciała, kolory itd.; por. , Leksykon liturgii, red. B. Nadolski, s. 31.

6 Termin pochodzenia łacińskiego: adaptatio, które oznacza „dostosowanie, przystosowanie do czegoś nowego".

7 D. Brzeziński, Wiara i jej celebracja w kulturze. Systematyzacja pojęć, „Teologia i Człowiek", 27 (2014) 3, s. 17; zob. także, Leksykon liturgii, red. B. Nadolski, s. 32; zob. S. Zięba i in., Akomodacja, w: Encyklopedia katolicka, t. 1, Lublin 1995, kol. 239-253. 
elementów kultury niechrześcijańskiej w sferę wyrażania i celebrowania chrześcijańskiej wiary, ale także chrześcijańskiej adaptacji elementów współczesnej kultury, często już postchrześcijańskiej, «naznaczonej obojętnością lub brakiem zainteresowania dla religii»"8.

Trzecim odpowiednikiem przysposobienia jest „,inkulturacja”. Polega ona na „chrześcijańskiej reinterpretacji i nadaniu nowego znaczenia, jeśli to możliwe, elementom kultury (głównie obrzędom przedchrześcijańskim). [...] Kościół modyfikuje znaczenie elementu danej kultury w ten sposób, aby mógł on adekwatnie wyrażać Misterium Chrystusa. [...] Inkulturacja staje się swoistą formą nawrócenia na wiarę chrześcijańską. Przykładem tego typu adaptacji u początków chrześcijaństwa są chrześcijańskie sakramenty, oczywiście w swej zewnętrznej formie, w stosunku do starożytnych misteriów pogańskich i religii żydowskiej”".

Po wstępnych informacjach, które dotyczyły zdefiniowanych pojęć, tak istotnych dla podejmowanego tematu, przedstawione zostaną poszczególne elementy, które weszły do obrzędowości chrześcijańskiego pogrzebu, a które zostały „oczyszczone” ze zbędnych elementów nieprzystających do wiary pierwszych wspólnot chrześcijańskich i wiary Kościoła. Jednak w tym miejscu należy zaznaczyć, że z pierwszych wieków kształtującego się Kościoła nie ma zbyt dużo przekazów źródłowych odnoszących się do omawianego tematu. Kościół z tamtego okresu nie ma ksiąg liturgicznych i jesteśmy skazani na szczątkowe informacje starożytnych autorów.

Na samym początku należy jeszcze krótko zastanowić się, po co jest tak naprawdę pochówek ciała. Od czasów starożytnych ludzkość wierzyła, że los człowieka nie kończy się wraz ze śmiercią ciała, ale że istnieje element niedostrzegalny ludzkim okiem, inny wymiar bytowania elementu niematerialnego człowieka określanego duszą. Stąd wynika przekonanie pierwszych rozwiniętych cywilizacji, że ciało zmarłego

${ }^{8}$ D. Brzeziński, Wiara i jej, s. 17 i n.; zob., Leksykon liturgii, red. B. Nadolski, s. 32; S. Pawlaczek, Akulturacja, w: Encyklopedia katolicka, t. 1, kol. 283 i n; J. Perszon, Akulturacja, w: , Leksykon teologii fundamentalnej, red. M. Rusecki i in., Lublin-Kraków 2002, s. 47-48.

${ }^{9}$ D. Brzeziński, Wiara i jej, s. 18. zob. także Leksykon liturgii, red. B. Nadolski, s. 32; S. Janeczek i in., Inkulturacja, w: Encyklopedia katolicka, t. 7, Lublin 1997, kol. 234-237; J. Perszon, Inkulturacja, w: Leksykon teologii fundamentalnej, red. M. Rusecki i in., s. $538-540$. 
należy zaraz po śmierci otoczyć szacunkiem i pochować, gdyż to ma wpływ na pośmiertny los elementu duchowego człowieka. W przypadku niepogrzebania lub zniszczenia ciała dusza człowieka nie znalazłaby spokoju i skazana byłaby na wieczną poniewierkę po tym świecie ${ }^{10}$. Dla chrześcijan pogrzeb, tak jak dla cywilizacji ościennych, pogańskich, jest „związany z oznakami czci dla zmarłych, przejętymi ze środowiska kulturowego, w którym chrześcijaństwo się ukształtowało. Do tych aktów należało np. mycie ciała zmarłego, owijanie w płótna i okładanie wonnościami, jak przygotowano do pogrzebu ciało Jezusa (por. J 19,39 i n. ${ }^{11}$. chrześcijanie przejmowali więc charakterystyczne dla danego regionu zwyczaje, dostosowując je do swojej wiary, do wiary Kościoła ${ }^{12}$. Pierwszym miejscem, skąd pierwotne wspólnoty czerpały zwyczaje, był judaizm, z którego chrześcijaństwo wzięło swój początek oraz zwyczaje, wykluczając to, co nie mieściło się w chrześcijańskiej nauce, to, co jest $\mathrm{z}$ nią sprzeczne ${ }^{13}$. W miarę jego rozprzestrzeniania się wspólnoty chrześcijańskie przejmowały elementy pogrzebu i wierzeń ze świata pogańskiego, ze świata przedchrześcijańskiego.

W pierwszych dwóch wiekach ery chrześcijańskiej pogrzeb sprawowany był niedługo po śmierci człowieczka, oczywiście po wcześniejszych przygotowaniach. I tak, jeżeli spodziewano się śmierci, umierającemu udzielano Wiatyku ${ }^{14}$. Można w tym oczywiście dopatrywać się podobieństwa do mitologii greckiej, gdzie zmarłemu wkładano do ust monetę, aby mógł nią opłacić przewoźnika dusz Charona, który miał przewieźć

${ }^{10}$ Por. J. Decyk, Ludzki i Boży wymiar śmierci w świetle kultu zmarlych. Studium liturgiczne, Warszawa 2000, s. 66.

11 Tamże, s. 67.

12 Por. Cz. Krakowiak, Z dziejów liturgii pogrzebu, „Studia liturgiczne” 8 (2012), s. 11 .

${ }^{13}$ Por. F. Stopniak, U źródeł chrześcijaństwa. Archeologia, Warszawa 1982, s. 50. Zob. także J. Decyk, Ludzki i Boży wymiar śmierci, s. 44.

${ }^{14}$ Por. Cz. Krakowiak, Pogrzeb chrześcijański, w: , Mysterium Christi, t. 4: Sakramenty $i$ sakramentalia, red. W.J. Świerzawski, Zawichost - Kraków - Sandomierz 2013, s. 317. Należy w tym miejscu wyjaśnić, że słowo „wiatyk” pochodzi od łacińskiego od słowa via - „droga”, i greckiego efodi,wn, który używany był w odniesieniu do pieniądza przeznaczanego na podróż. Na temat pojęcia „wiatyk“ zob. O. Nußbaum, Die Aufbewahrung der Eucharistie, Bonn 1979, s. 64-74. 
ją przez rzekę Styks do świata zmarłych. W rytach pogańskich w obrzęd pogrzebu włączona była ofiara dla śmierci. Analogiczne odniesienie takie odnajdujemy w chrześcijaństwie, w drugim stuleciu, kiedy Eucharystia sprawowana była zaraz po pogrzebie jako sposób przebłagania Boga za grzechy zmarłego i tym samym osiągnięcia przez niego zbawienia wiecznego ${ }^{15}$. W tym miejscu „Warto nadmienić, że w różnych regionach świata chrześcijańskiego istniała praktyka umieszczania kawałka chleba eucharystycznego w grobie, a konkretnie w ustach zmarłego, co najprawdopodobniej nawiązywało do tzw. obola dla Charona" ${ }^{16}$. Jak się można domyślać, zwyczaj ten był dość powszechny w tamtym czasie, ponieważ liczne synody (np. synod biskupów północnoafrykańskich w Hipponie [393 rok] ${ }^{17}$, synod w Kartaginie [525 rok], synod w Auxerre [578 rok] oraz synod w Trullo [691 rok]) zakazywały tej praktyki swoim wiernym $^{18}$. Obok praktyki umieszczania monety i chleba eucharystycznego chrześcijanie w IV i V wieku mieli zwyczaj, który osądzany był różnie przez ojców Kościoła, a który określany był terminem refrigerium ${ }^{19} z a$

15 Por. J.A. Jungmann, Liturgia pierwotnego Kościoła do czasów Grzegorza Wielkiego, tłum. T. Lubowiecka, Kraków 2013, s. 226.

${ }^{16}$ A. Muc, Śmierć i pogrzeb $w$ chrześcijańskim Egipcie (IV-VIII w.). Studium na podstawie źródeł literackich i archeologicznych, Kraków 2013, s. 59; zob. Leksykon liturgii, red. B. Nadolski, s. 1672.

17 Przykładem takiego zarządzenia jest wypowiedź biskupa Aureliusza podczas synodu w Hipponie: „Illud autem quiniam praesentibus corporibus nonnulli audeant sacrificia celebrare et partem corporis sancti cum exanimi cadavere communicare arbitror prohibendum. Superest ut, si placet, vestra sanctitas cen seat” („Sądzę, iż tego zaś należy zakazać, ponieważ niektórzy ośmielają się sprawować ofiarę przy zwłokach i dzielić cząstkę świętego ciała ze zmarłym”. Dokumenty synodów od 381 do 431 roku, red. A Baron, H. Pietras, tłum. S. Poręba, Synody i Kolekcje Praw, t. 4, seria Źródła Myśli Teologicznej, t. 52, Kraków 2010, s. $\left.61 / 61^{\star}\right)$.

18

19 „Terminy «refrigeratio», «anapsiche», «anapsiksis» przybrały u chrześcijan różne znaczenia. Znaczenie klasyczne wiąże się ze słowem «refrigerare» równoznaczne z greckim «anapsichein». W sensie materialnym oznacza ulgę, pociechę, posiłek, wsparcie, ucztę. W tekstach oznacza także odpoczynek, spokój, pokój i ten sens przeważa nad pierwotnym, podczas gdy znaczenie realne, to pierwsze, niekiedy zmienia się w życzenie szczęścia wiecznego. [...] Niezależnie jednak od przeważnego sensu symbolicznego pewna grupa tekstów mówi o refrigerium w sensie posiłku fizycznego dla zmarłego i potwierdza zwyczaj, ceremonię pogrzebową spełnioną przez żyjących, o czym są wyraźne wzmianki 
zmarłych $^{20}$. Ten pogański zwyczaj szczególnie popularny był w Afryce, gdzie bardzo chętnie przejmowali go chrześcijanie ${ }^{21}$. Patrząc od strony zewnętrznej, refrigeria posiadały cechy bankietu pogańskiego. Refrigerium przetransponowane na sposób chrześcijański zmienia swój charakter i jego zasadniczym celem jest wspieranie duszy przez Mszę św. i świadczenie jej pomocy przez modlitwę̨2 , także jest uobecnieniem przyszłej uczty, uczty niebiańskiej ${ }^{23}$. Należy nadto nadmienić, że „Ten nowy duch rytu [...] spełniany $\mathrm{w}$ rocznicę śmierci męczennika czy zmarłego tłumaczy także, jak ów dzień z pochodzenia smutny, z czasem stał się dies natalis duszy, wprowadzający ją do życia wiecznego. Ryt refrigerium polegał na libacji wina lub prawdziwym przyjęciu, uczcie, zwanej agapą. Nie jest to pociecha w znaczeniu moralnym. Agapa miała charakter eucharystyczny, od czasu do czasu odprawianą ją także na cmentarzach z okazji rocznicy męczennika i innych okazji. Nie należy jej mieszać z bankietem ku czci zmarłego, którego właściwa nazwa to refrigerium” ${ }^{24}$. Z kolei Joseph A. Jungmann pisze, że „Refrigerium to był posiłek spożywany przy różnych okazjach na grobie zmarłego. Uważano, że zmarły jest też na nim obecny - pozostawiano dla niego miejsce i odkładano specjalną porcję. W Rzymie można zauważyć pogańskie miejsca pochówku z małymi zagłębieniami w posadzce i rurą spuszczoną w głąb do miejsca, gdzie spoczywało ciało; przez tę rurę nalewano zmarłemu napoje. Taki zwyczaj obchodzenia styp (death-meal) panował również wśród chrześcijan, chociaż nie chodziło o nakarmienie samego zmarłego, lecz o ożywienie pamięci o nim. A zatem była to praktyka obojętna moralnie, którą chrześcijanie mogli zachowywać" 25 . Jednakże zwyczaj ten w niektórych miejscach został zabroniony lub ograniczony $^{26}$, a to z powodu tego, że refrigeria stały się miejscem, gdzie

w tekstach". Wśród tych tekstów należy przywołać: 2 Tm 1,16. F. Stopniak, U źródeł, s. 111; zob. Cz. Krakowiak, Pogrzeb chrześcijański, s. 318 (przyp. 3).

20 Por. J.A. Jungmann, Liturgia pierwotnego, s. 226 i n.

${ }^{21}$ Por. Leksykon liturgii, red. B. Nadolski, s. 1281.

22 Por. F. Stopniak, U źródeł, s. 112.

${ }^{23}$ Por. B. Nadolski, Liturgika, t. 3: Sakramenty, sakramentalia, błogosławieństwa, Poznań 2012², s. 40.

24 F. Stopniak, U źródet, s. 112.

25 J.A. Jungmann, Liturgia pierwotnego, s. 227.

${ }^{26}$ Ambroży w Mediolanie zakazał w całości obchodzenia refrigeriów, a z kolei 
zaczęto nadużywać alkoholu, wskutek czego dochodziło do niestosownych zachowań. Kościół zakazał tego zwyczaju ze względu na owe nadużycia, a nie dlatego, że jego korzenie były pogańskie ${ }^{27}$.

Wśród powszechnie panujących zwyczajów kultur pogańskich zasadniczo stosowane było spalanie zwłok. Wśród chrześcijan zwyczaj ten nie zadomowił się, dlatego że chrześcijaństwo wyrosło z tradycji żydowskiej, dla których powszechna była inhumacja w ziemi. Dowody na to odnajdujemy w katakumbach, gdzie nie odnaleziono urn z prochami ludzkimi. Drugim powodem, dla którego chrześcijanie nie dopuszczali się kremacji ciała, był zwyczaj przejęty z pogrzebu Jezusa ${ }^{28}$, którego ciało nie zostało spalone, lecz złożone w grobie (por. Mt 27,60; Mk 15,46; Łk 23,53; J 19,42). Natomiast trzecim powodem, dla którego chrześcijaństwo nie stosowało we wczesnym okresie swojego istnienia kremacji, jest to, że „Nie należy niszczyć gwałtownie rzeczy uświęconej i należącej mistycznie do Chrystusa. Należy ją pozostawić naturalnemu rozkładowi, tym bardziej, jeśli rozkład ten ma głębszy sens" ${ }^{\prime 2}$. W dodatku sam cesarz Karol Wielki zakazał spalania ciała człowieka, który uważał na zwyczaj pogański: „Jeśli ktoś spaliłby według rytu pogan ciało zmarłego człowieka i jego kości w popiół zamienił, będzie ukarany śmiercią"30.

Liturgia pogrzebu w początkowych wiekach chrześcijaństwa, w swej pierwotnej wersji nie była rozbudowana. Nacisk kładziono tu na liturgię śmierci ${ }^{31}$. Wśród czynności, które składają się na ową liturgię zaliczyć należy Wiatyk, czyli zadatek na moment migratio ad Dominum ${ }^{32}$, o którym mowa była powyżej, modlitwy (commendatio ${ }^{33}$ ), a także czytanie przy

Augustyn zmienił ten zwyczaj i pozwolił swoim wiernym na przynoszenie skromnych darów na grób zmarłego, a także tego, by dary z uczty rozdawano biednym; por. tamże.

27 Por. tamże.

${ }_{28}$ Por. R. Pierskała, Kremacja ciała i pogrzeb katolicki, „Studia liturgiczne” 8 (2012), s. $80-81$.

${ }^{29}$ F. Stopniak, U źródet, s. 50.

30 „Si quis corpus defuncti hominis secundum ritum paganorum fiamma consumi fecerit, et ossa eius ad cineram redierit, capite punietur”. PL 97, 145, cyt. za: Cz. Krakowiak, Pogrzeb chrześcijański, s. 332.

${ }^{31}$ Por. J. Decyk, Eschata w oficjum za zmartych Liturgii Godzin, Warszawa 2003, s. 21.

32 Por. Leksykon liturgii, red. B. Nadolski, s. 1671.

${ }_{33}$ Commendatio $\mathrm{w}$ pierwotnym znaczeniu dotyczyło zmarłego i oznaczało po- 
konającym opisu męki Pańskiej wg Ewangelii św. Jana, a bezpośrednio po śmierci: zamknięciu oczu i ust ${ }^{34}$. W dalszej kolejności przystępowano do mycia ciała, namaszczenia go wonnościami, owijania w całun, po czym ciało składano na łożu (feretrum), czuwano przy nim, a następnie po uroczystej procesji składano w grobie. Trzeba tu nadmienić, że takie czynności jak: balsamowanie czy namaszczanie ciała wonnościami, owijanie w całun, przynoszenie kwiatów czy zapalanie świateł należały do zwyczajów świata pogańskiego czy izraelskiego ${ }^{35}$. Obok tych zwyczajów przejęto "flambeaux (ozdobne żagwie czy świeczniki) zdobiące po dziś dzień karawany jako wyobrażenie lux aeterna [...] oraz zwyczaj niewstępowania do kościoła $\mathrm{w}$ ramach pogrzebu. Pogańscy kapłani uznaliby, że zmarły, którego przynosi się do świątyni, wnosi do niej nieczystość. Chrześcijanie - choć nie nadali temu żadnego znaczenia - przyjęli na początku zwyczaj niewstępowania do kościoła, a zatem i nieodprawiania w nim Mszy świętej”36.

W dalszej części nie zostaną omówione wszystkie czynności, ponieważ nie wszystkie mają mocne zakorzenienie w pogaństwie. Odwołamy się w tym miejscu tylko do niektórych, które mają ważne znaczenie dla omawianego tematu.

grzeb, w ujęciu ogólnym, lub prośbę o przyjęcie zmarłego, w liturgii rzymskiej VII i VIII w. W skład wchodziło: responsorium Subvenite (Pośpieszcie) z wersetem Requiem aeternam (Wieczny odpoczynek), Ps 114 (113A); 115 (113B); 116 (114-115); 117 (116); 118 (117); 119 (118); 120 (119). Z kolei w księgach galijskich omawiany termin odnoszono do modlitw przed śmiercią. Ze stuprocentową pewnością można stwierdzić, że od VIII wieku (z sakramentarzy tego stulecia) commendatio składało się z: Proficisce anima christiana (Duszo chrześcijańska, zejdź z tego świata); Deus misericors (Boże miłosierny); Tibi Domine commendamus (Tobie, Panie polecamy); Commendo te Omnipotenti Deo (Polecam ciebie Wszechmogacemu Bogu); Libera me (Wybaw); Suscipe Domine (Przyjmij, Panie); Diri Domine (Ulecz ranę); Pio recordationis affectu (Pobożnie polecamy Ci); Suscipe Domine animam (Przyjmij, Panie, duszę). Dodatkowo należy nadmienić, że słowo commendatio pochodzi z odmawianego przez Jezusa Chrystus Psalmu 31, wersetu 6: „W Twoje ręce oddaję ducha mego" (por. Łk 23,46). Stwierdzenie to było aktem dobrowolnego oddania życia za dzieło zbawienia, por. B. Nadolski, Liturgika, t. 3, s. 393.

${ }^{34}$ Por. Leksykon liturgii, red. B. Nadolski, s. 790.

35 Por. Cz. Krakowiak, Pogrzeb, w: Encyklopedia katolicka, t. 15, Lublin 2011, k. 993-994.

${ }^{36}$ J. Decyk, Eschata w oficjum za zmarlych, s. 22. 
Wśród pierwszych czynności, które należało wykonać po śmierci człowieka, jest zamknięcie oczu oraz ust. Zwyczaj ten był popularny w świecie starożytnym i we wczesnym chrześcijaństwie oraz w kulturze bizantyńskiej. I tak czynność zamknięcia oczu i ust była czynnością naturalną i mającą podstawy praktyczne. Jednak czynności te tłumaczono symbolicznie. Wierzono, że przez otwarte usta dusza człowieka może $\mathrm{z}$ powrotem wrócić do ciała, a także $\mathrm{w}$ ten sam sposób przeniknąć może do niego zły duch ${ }^{37}$.

Następnym zabiegiem było obmycie i namaszczenie ciała wonnościami (m.in. mirrą i aloesem, por. J 19,39 i n.). Obmycie miało także symbolizować usunięcie wszelkiej zmazy, która powstać mogła pod wpływem działania złych mocy. Z kolei użycie wonności, które występowało w kulturze pogańskiej oraz żydowskiej oznaczało hołd dla zmarłego. W tym możemy odnaleźć analogię do chęci namaszczenia przez kobiety ciała Jezusa (por. Mk 16,1; Łk 24,1) ${ }^{38}$.

W dalszej kolejności ubierano i owijano ciało całunem. Do tej czynności używano tkanin z lnu. Praktyka w początkach chrześcijaństwa przejęta została ze środowiska żydowskiego (por. J 19,40). Dbano także przy tej okazji o odpowiednie ułożenie zmarłego, np. o założenie splecionych dłoni na brzuchu lub klatce piersiowej oraz o związanie stóp. Dodatkowo w praktyce chrześcijańskiej było przykrywanie materiałem twarzy zmarłego ${ }^{39}$. Odniesienie to znajduje swoją podstawę $\mathrm{w}$ tradycji żydowskiej, a także w Ewangelii św. Jana: „Tam spostrzegł [Piotr] leżące płótna oraz chustę, która była na Jego głowie" (20,6 i n.).

Jeśli chodzi o ułożenie zwłok, to w pogaństwie praktykowano dwie pozycje: ułożenie jak podczas snu lub ułożenie płodu w łonie matki. I tak pozycje te „W pogańskiej praktyce grzebania zmarłych można również odnaleźć ślady swoistej magii rezurekcyjnej, która wyraża się przez określoną formę ułożenia ludzkiego ciała [...]. To ułożenie ciała miałoby zapewnić zmarłemu nowe narodzenie" 40 .

37 Por. A. Muc, Śmierć i pogrzeb, s. 55.

${ }^{38}$ Por. tamże.

39 Por. tamże.

${ }^{40}$ J. Decyk, Ludzki i Boży wymiar śmierci, s. 47. 
Przechodząc teraz do publicznej modlitwy Kościoła za zmarłych, należy wspomnieć, że jej kształtowanie „wiążę się u jej początków z tzw. Vigiliae, czyli czuwaniami, które dzieliły się na niedzielne i cmentarne. Niedzielne były odprawiane w nocy z soboty na niedziele (por. Dz 12,12; 20,7). Prawdopodobnie wzorem dla nich były modlitwy synagogalne" ${ }^{41}$.

Wśród następnych części pogrzebu należy wspomnieć o lamencie, który towarzyszył procesji przeniesienia ciała na miejsce wiecznego spoczynku. W kulturze starożytnego Izraela „«wyspecjalizowały się» [...] kobiety, stanowiące rodzaj zawodowych «płaczek». Z tych lamentacji wyrosły treny żałobne [...]. Treny wykonywane zawodowo nie miały charakteru religijnego, nie wiązały się z wiarą w Boga Jahwe. Wyrażały ludzkie uczucia i emocje, łączyły się z osobą zmarłego. [...] I tak [chrześcijanie] pogańskie treny, opłakiwanie zastępowali śpiewem psalmów, czytaniem Pisma św., modlitwami. W ten sposób powstał ordo defunctorum, używając dzisiejszej nazwy"42. Jak wiadomo, zwyczaj lamentowania był odrzucony, ponieważ w chrześcijaństwie na moment śmierci patrzono jako na dies natalis. Była to chwila związana raczej z radością, a nie ze smutkiem ${ }^{43}$. Przykładem takiego pojmowania śmierci są słowa św. Augustyna, który po śmierci matki, św. Moniki, pisał: „Nie wydało się nam godziwe, żeby śmierć takiej matki oblewać łzami, osnuwać skargą i lamentem. Tak się zazwyczaj opłakuje śmierć uważaną za nieszczęście albo całkowite unicestwienie" 44 . Jednak jak się okazuje, pomimo zakazów zwyczaj lamentowania był nadal praktykowany, mimo że w ich miejsce zaczęto śpiewać psalmy i hymny. Dodatkowo w tradycji bizantyjskiej do płaczu dochodziły także: uderzenia w klatkę piersiową pięściami oraz w głowę i rwanie włosów ${ }^{45}$.

Do ostatnich czynności towarzyszących uroczystości pogrzebowej przy ciele zmarłego zaliczyć należy polecenie i ostatnie pożegnanie zmarłego. Jest to jeden $\mathrm{z}$ najnowszych elementów chrześcijańskiej liturgii pogrzebu,

$41 \quad$ Tenże, Eschata $w$ oficjum za zmarlych, s. 20.

${ }^{42}$ B. Nadolski (red.), Leksykon liturgii, s. 789 i 793; por. M. Kunzler, Liturgia Kościoła, tłum. L. Balter, Poznań 1999, s. 511; zob. B. Nadolski, Liturgika, t. 3, s. 386.

${ }^{43}$ Por. A. Muc, Śmierć i pogrzeb, s. 57.

${ }^{44}$ Augustyn, Wyznania, tłum. Z. Kubiak, Kraków 2007, s. 265.

${ }_{45}$ Por. A. Muc, Śmierć i pogrzeb, s. 57; zob. Euzebiusz z Cezarei, Życie Konstantyna, tłum. T. Wnętrzak, seria Źródła Myśli Teologicznej, t. 44, Kraków 2007, s. 242. 
który wszedł w jej struktury. Jest to również element obcy wierze chrześcijańskiej. Został przejęty od narodów pogańskich i wywodzi się ze starorzymskiej tradycji liturgicznej, a także spotyka się ją w liturgiach wschodnich. Kościół, adoptując ten zwyczaj do swojej obrzędowości, nadał mu własne, głębsze znaczenie. Element ten wyraża pożegnanie wspólnoty ze zmarłym jej członkiem i pogrzebanie go, a także zawiera w sobie prośbę Kościoła doczesnego skierowaną do Boga, aby przyjął duszę zmarłego do siebie, dzięki czemu zmarły może przebywać w Kościele tryumfującym. Dodatkowo obrzęd ten charakteryzuje się uwielbieniem Boga za życie człowieka, który odszedł do wieczności i za wszelkie dobra, które otrzymał od Boga. Polecenie i ostatnie pożegnanie w tym ujęciu ukazują prawdę wiary chrześcijańskiej i nadzieję, że śmierć jest tylko czasowym rozdzieleniem ludzi, ponieważ kiedyś nastąpi ponowne z nimi spotkanie w Domu Ojca (por. J 14,2) ${ }^{46}$.

Dość istotnym elementem, który występował w każdej kulturze świata starożytnego, w jego kulcie, było ukierunkowanie geograficzne ${ }^{47}$. Uprzywilejowaną stroną był Wschód, znad którego nad obszar ziemi wschodziło słońce, zwiastujące nowy dzień. I tak „Wschód, skąd wznosi się słońce, wydawał się dla ludzi miejscem, skąd wywodzi się życie, moc i szczęście. I tak wschodzące słońce stało się symbolem boskości; stąd już oczywiście jeden krok do uznania słońca za bóstwo, co często miało miejsce"48. Stąd tak liczy i mocy kult tego ciała niebieskiego w starożytnych cywilizacjach. Jeśli chodzi o ukierunkowanie grobów to Joseph A. Jungmann w swoim dziele, który poświęcił pierwotnej liturgii Kościoła, wspomina, że na cmentarzach w Tyrolu i Austrii zmarli chowani są twarzą do wschodu, skąd blask słoneczny ma ich opromieniać. W dalszej części swojego wywodu, który odnosi się do usytuowania zmarłych, pisze: „Zmarli są jak wielka armia wypatrująca Tego, który zmartwychwstał i czekają na Jego zawołanie ${ }^{49}$, kiedy wezwie także ich

${ }^{46}$ Por. Cz. Krakowiak, Pogrzeb chrześcijański, s. 325.

47 Szerzej na temat orientacji (Conversi ad Dominum - Zwrócenie ku Panu) w kulcie, w liturgii i architekturze kultycznej zob. B. Nadolski (red.), Leksykon liturgii, s. $1128-1134$.

48 J.A. Jungmann, Liturgia pierwotnego, s. 217 i n; zob. J. Ratzinger, Duch liturgii, tłum. E. Pieciul, Poznań 2002.

49 „Uroczyście zapewniam was: Nadchodzi godzina - a właściwie już jest - kiedy zmarli usłyszą wołanie Syna Bożego. Ci, którzy Go usłyszą, będą żyli” (J 5,25). 
do zmartwychwstania. [...] Nad bramą jednego z większych cmentarzy Tyrolu ten symbolizm zawarty jest w jednym słowie: Resurrecturis" ${ }^{20}$. Dlatego w II wieku chrześcijaństwa pojawia się praktyka, aby zmarłego chować w kierunku wschodnim, skąd, jako wschodzące Słońce, ma przyjść zmartwychwstały Jezus Chrystus ${ }^{51}$.

Następną rzeczą, o której należy wspomnieć, jest grób. Warte chwilowego zatrzymania jest to, że same formy grobu nie odbiegały od tych, które znane były w kulturze przedchrześcijańskiej. Wśród form grobów należy wyróżnić: groby ziemne, groby niszowe tzw. katakumbowe, grobowce kamienne ${ }^{52}$, a także jaskinie wykuwane w skale, hypogea ${ }^{53}$, groby murowane, krypty, $z$ czasem pojawiły się trumny, a od trzeciego stulecia naszej ery sarkofagi, które coraz bardziej zyskiwały na popularności ${ }^{54}$.

Wśród wielości form kultu wobec zmarłych często stosowane było zapalanie świata na grobach najbliższych. Jest to zwyczaj zakorzeniony w kulturze pogańskiej. Ze względu na to Kościół był dość sceptyczny wobec tej praktyki wiernych. Dodowem na nieprzychylność Kościoła wobec tego zwyczaju jest postanowienie synodu w Elwirze (306 rok) ${ }^{55}$. Wśród praktyk, które odbywały się na grobach zmarłych, wspomnieć należy o zwyczaju, „który później ustalił się także i u chrześcijan, [i] do-

${ }^{50}$ J.A. Jungmann, Liturgia pierwotnego, s 224.

${ }^{51}$ Por. B. Nadolski (red.), Leksykon liturgii, s. 790; zob. Benedykt XVI, Przedmowa do wprowadzającego tomu moich pism, w: J. Ratzinger, Opera Omnia, red. M. Górecka, K. Góźdź, t. 11, Lublin 2012, s. 3.

${ }^{52}$ „Zgodnie z panującym przeświadczeniem, że kamień jest nosicielem płodnego życia oraz symbolem trwałości. Podobnie też jaskinia uchodziła za symbol życiodajnego łona”. J. Decyk, Ludzki i Boży wymiar śmierci, s. 48.

53 „ «Hypogeum» Słowo gr. oznaczające w starożytności pomieszczenie (zwykle wąskie) podziemne monumentu pogrzebowego. Chrześcijanie odnosili to słowo do pokoi i galerii katakumbowych". Leksykon liturgii, red. B. Nadolski, s. 530.

${ }^{54}$ Por. A. Muc, Śmierć i pogrzeb, s. 59 i n., por. J. Decyk, Ludzki i Boży wymiar śmierci, s. 47, zob. F. W. Deichmann, Archeologia chrześcijańska, tłum. E. Jastrzębowska, Warszawa 1994, s. 48.

55 „Cereos per diem placuit in coemeterio non incendi, inquietandi enim sanctorum spiritus non sunt. Qui haec non observaverint arceantur ab ecclesiae communione” - „Nie należy w dzień palić świec na cmentarzu, aby nie niepokoić duchów świętych. Kto się nie dostosuje, ma być odsunięty od wspólnoty Kościoła”. Dokumenty synodów od 50 do 381 roku, red. i tłum. A. Baron, H. Pietras, Synody i Kolekcje Praw, t. 1, seria Źródła Myśli Teologicznej, t. 37, Kraków 2006, s. 55/55*. 
tyczył kwiatów. W okresie przed Konstantynem chrześcijanie nie używali przy grobach kwiatów, nie ozdabiano nimi głowy, gdyż według Tertuliana i Klemensa Aleksandryjskiego był to znak kultu bałwochwalczego. Od IV w. zdobi się groby koronami z kwiatów. Według Prudncjusza kwiatami okrywa się kości” 56 .

W pewnych kulturach, w których rozwijało się chrześcijaństwo, panowało przekonanie, że złe duchy mogą wywierać negatywne oddziaływanie na zmarłych (niepokoić duchy zmarłych m.in. tym, o czym była mowa wcześniej, czyli zapalaniem świec). Duchy te znajdować się miały w powietrzu. Przekonanie to dość mocno zakorzeniło się w wierzeniach chrześcijańskich. Stąd pojawiały się na grobach liczne amulety, których zadaniem była ochrona zmarłych przed złymi mocami, które mogły znieważyć miejsce wiecznego odpoczynku. Na grobach pojawiały się więc: gwoździe, podeszwy z żelaza, dzwonki, srebrne i złote płytki, figurki robaków, a także wezwania do Boga, aniołów, a także inne dziwne przedmioty, których obecność tłumaczy się przesądami. Jednak wśród grobów chrześcijan spotyka się kryptogramy dotyczące wiary chrześcijańskiej. Wśród nich najbardziej rozpowszechnionym był akrostych: IX $\Upsilon \Upsilon \Sigma^{57}$. Dodatkowo groby polewano winem lub pachnącymi olejkami, „Np. Paulin z Noli [†431] referuje, iż lud wierzył w swej niewiedzy, jakoby święci odczuwali radość, kiedy groby polewano winem. Podobne myśli towarzyszyły zapewne wielu chrześcijanom, którzy wylewali pachnące olejki na groby" 58 .

Ze zwyczajami, o których wspomniano, wiąże się praktyka spotykania się przy grobach zmarłych na uczcie w określone dni, co chrześcijanie przejęli z pogaństwa. Tymi dniami był: trzeci, siódmy i trzydziesty, a i niekiedy czterdziesty dzień po śmierci oraz dies natalis i w rocznicę śmierci, czyli rocznicę narodzin dla nieba. Powstawało to pod wpływem przekonań, że także zmarły bierze udział w uczcie, tzw. refrigerium. Jed-

${ }^{56}$ F. Stopniak, U źródeł, s. 116; zob. Minucjusz Feliks, Octavius, tłum. J. Sajdak, Poznań 1925, s. 24; Leksykon liturgii, red. B. Nadolski, s. 790.

57 F. Stopniak, $U$ źródeł, s. 116. Wspomniany w tekście akrostych tłumaczy się, jako „ryba”. Jego słowa są wyznaniem wiary w Jezusa Chrystusa Syna Bożego. I -’I v̂ Zbawiciel.

58 Tamże. 
nak chrześcijanie, przejmując ten zwyczaj, w miejsce wspomnianych uczt sprawowali Eucharystię ${ }^{59}$. „W Mszale rzymskim na zakończenie Missa in die obitus (Msza w dniu śmierci), wciąż odnajdujemy rubrykę: „In die tertio, septimo et trigesimo depositionis defunctorum dicitur missa ut Supra" (W trzecim, siódmym i trzydziestym dniu po pogrzebie odprawia się Mszę jak wyżej); taka sama Msza żałobna mogła być odprawiana nie tylko w dniu pogrzebu [...]. «Miesięczne wspomnienie» jest żywą tradycją $\mathrm{w}$ wielu krajach, a nawet protestanci $\mathrm{w}$ pewnych rejonach mają nabożeństwo wspomnieniowe w miesiąc po śmierci" ${ }^{60}$. W liturgii egipskiej, tak jak w rzymskiej uprzywilejowano trzeci, siódmy i trzydziesty dzień. U Syryjczyków z kolei dzień trzeci, dziewiąty i czterdziesty. Dni te oczywiście pochodzą z tradycji przedchrześcijańskiej, głównie ze starożytnego Wschodu. W starożytnej Grecji oraz u Persów wspomnienie zmarłych odbywało się trzeciego i dziewiątego dnia po śmierci. W odniesieniu do żałoby należy zaznaczyć, że zarówno w Azji Mniejszej, jak i starożytnym Izraelu trwała ona siedem dni. Jako przykład dla tego ujęcia posłużą postaci ze Starego Testamentu: Jakub i Judyta. Żałoba po Jakubie i Judycie trwała siedem dni (por. Rdz 50,10; Jdt 16,24). U Greków i Persów żałoba trwała dziewięć dni ${ }^{61}$.

Dzień trzeci po śmierci związany był $\mathrm{z}$ wierzeniami ludów starożytnych, w których opinii dusza nie opuszcza ciała od razu po śmierci, lecz pozostaje przez pewien czas przy nim. W zasadzie przyjęto tu okres trzech dni, lecz w innych wierzeniach mówiono o siódmym dniu. Panował także pogląd, że dusza jest tak długo na ziemi, dopóki ciało nie ulegnie ostatecznemu rozkładowi. Granicą tego definitywnego rozpadu ciała i odejścia duszy jest dzień trzydziesty lub czterdziesty po śmierci. U Greków wiąże się to z przekonaniem, że człowiek otrzymuje duszę dopiero w czterdziestym dniu od momentu poczęcia, bo wtedy zarodek przyjmuje postać człowieka, dziecka. Z kolei po śmierci ów proces

${ }_{59}$ Por. J. Decyk, Eschata w oficjum za zmartych, s. 22; por. Cz. Krakowiak, Pogrzeb chrześcijański, s. 318; por. Cz. Krakowiak i in., Pogrzeb, k. 994; por. M. Kunzler, Liturgia Kościoła, s. 511.

60 J.A. Jungmann, Liturgia pierwotnego, s. 229.

${ }^{61}$ Por. tamże, s. 229-230. 
przebiega w kierunku odwrotnym ${ }^{62}$. W odniesieniu do chrześcijaństwa, Konstytucje apostolskie mówią: „Należy celebrować trzeci dzień po śmierci [zmarłego] psalmami i modlitwami ze względu na Tego, który został wskrzeszony w ciągu trzech dni. Dzień dziewiąty na pamiątkę żywych i umarłych oraz dzień czterdziesty, zgodnie z pradawnym przykładem, ponieważ $\mathrm{w}$ ten sposób lud opłakiwał Mojżesza. Należy też obchodzić rocznicę śmierci dla wspomnianego zmarłego"63.

Ostatnią rzeczą, o której należy wspomnieć w odniesieniu do liturgii pogrzebu i modlitwy za zmarłych, swą krótkie wezwania odnoszące się do wiecznej szczęśliwości. Pierwszym z nich jest prośba o wieczny odpoczynek. Podstawę tego wezwania znajdujemy w literaturze apokryficznej, która weszła do liturgii rzymskiej, a zaczerpnięta została z 4 Księgi Ezdrasza $^{64}$. Kolejną prośbą za zmarłych jest apel o światłość wiekuistą dla nich. Światło w chrześcijaństwie jest symbolem Jezusa Chrystusa, który oświeca drogi człowieka (por. J 8,12; Iz 9,1; Iz 49,6). Jednak symbolika światła obecna w kulcie pogańskim została przejęta przez Kościół, który nadał jej jeszcze głębsze znaczenie, o czym mowa była wcześniej. Ostatnim wezwaniem jest prośba o pokój wieczny. Wyrażenie „pokój” (hebr. szalom) oznacza jedność, szczęście, spokój oraz wyciszenie, którego pragnie człowiek i do którego dąży ${ }^{65}$.

Reasumując wszystko, co do tej pory zostało powiedziane na temat pogańskich elementów w liturgii chrześcijańskiego pogrzebu, należy stwierdzić, że liturgia pogrzebu w Kościele pierwszych wieków to nie

${ }^{62}$ Por. tamże, s. 231.

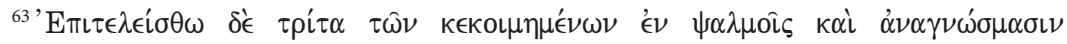

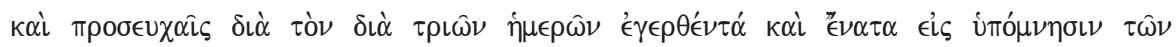

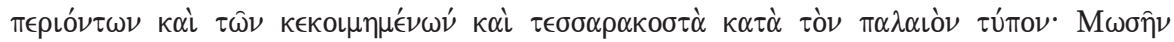

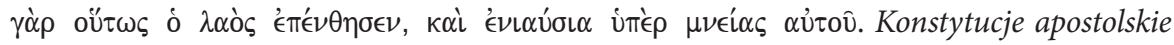
oraz Kanony Pamfilosa $z$ apostolskiego synodu $w$ Antiochii, Prawo kanoniczne świętych Apostołów, Kary świętych Apostołów dla upadłych, Euchologion Serapiona, red. A. Baron, A. Caba, tłum. S. Kalinkowski, Synody i Kolekcje Praw, t. 2, seria Źródła Myśli Teologicznej, t. 42, Kraków 2007, s. 268/268*.

${ }^{64}$ „Expectate pastorem vestrum, requiem aeternitatis dabit vobis. Parati estote ad praemia regni, quia lux perpetua lucebit vobis per aeternitatem temporis" (4 Ezd 2,34 i n.).

${ }^{65}$ Por. Cz. Krakowiak, Pogrzeb chrześcijański, s. 340-341. 
tylko twór złożony z nowych elementów, skonstruowanych na potrzeby rozwijającej się religii, ale to także bogactwo różnych elementów charakterystycznych dla rozwiniętych cywilizacji tamtego okresu, które przyczyniły się do stworzenia swoistej i całościowej mozaiki charakterystycznej dla wiary chrześcijańskiej. Wierzenia te, jak to niejednokrotnie zostało zaznaczone w tekście, zostały przetransponowane i uaktualnione w duchu wiary chrześcijańskiej. Jak wynika $\mathrm{z}$ niniejszego opracowania, chrześcijaństwo dość chętnie przejmowało elementy kultu religijnego z innych wierzeń, nadając im nowe znaczenie, znaczenie w duchu Ewangelii, w duchu nauczania Jezusa Chrystusa zmartwychwstałego.

Streszczenie. Niechrześcijańskie źródła liturgii pogrzebu i kultu zmarłych wczesnego chrześcijaństwa. Artykuł w sposób systematyczny ukazuje stosunek żyjących do ciała zmarłego, do „kultu”, którym go odtaczano. Wraz z zaistnieniem nowej religii i w odpowiedzi na fakt śmierci wiara chrześcijańska rozpoczęła proces kształtowania własnej liturgii pogrzebu. Rozpoczęło się poszukiwanie lokalnych obrzędów oraz elementów niechrześcijańskich ceremoniałów pogrzebowych. Chrześcijaństwo, przejmując te elementy, które wpisywały się w kontekst doktrynalny, dokonywało ich adaptacji i oczyszczenia z naleciałości, które były niezgodne z nauczaniem Kościoła ówczesnej doby. Pracę można podzielić na trzy części: wyjaśnienie podstawowych terminów związanych z przejmowaniem obcych elementów z religii przedchrześcijańskich; poszczególnych czynności, które odbywały się nad ciałem zmarłego, oraz czynności, które odbywały się nad grobami zmarłych. Z rozważań tych można zauważyć, że obrzędy pogrzebu chrześcijańskiego to nie jest zupełna nowość, tak jak religia, która się narodziła, ale to pewien ciąg czynności wypracowanych przez poprzednie pokolenia i dostosowanych do nauczania Jezusa, do ducha Ewangelii.

Słowa klucze: kult; liturgia pogrzebu; śmierć; obrzęd; ciało; modlitwa za zmarłych.

Abstract. Non-Christian sources of the funeral liturgy and the deceased cult in the Early Christianity. The article presents, in an orderly way, the living people's attitude to the dead body, to the cult which it was surrounded by. Along with appearing of the new religion and in the reaction on the fact of death, Christianity initiated the process of creating its own funeral liturgy. The process of searching and adjusting local rites and non-Christian elements of the funeral ceremony began. Christianity, taking those elements which could have been a part of the doctrinal context, adapted them and purified of the traces which were against the then Church teaching.

The paper can be divided into three parts: explaining the basic terms, connected with taking the extraneous elements out of the religions before Christianity; particular 
activities that were taking place on the body of deceased and activities progressed over the graves of the dead. Due to those deliberations, it can be presumed that Christian funeral rites are not an absolute novelty, as the arisen religion but it is a series of activities, elaborated by the previous generations and adjust up to the teaching of Jesus Christ and the spirit of the Gospel.

Keywords: cult; funeral liturgy; death; rite; body; prayer for the dead (caddish). 